\title{
Regulation of Mucosal Phosphof ructokinase in the Small Intestine of the Streptozotocin-Diabetic Rat
}

\author{
A.Jamal and G. L. Kellett \\ Department of Biology, University of York, Heslington, York, UK
}

\begin{abstract}
Summary. The total activity of mucosal phosphofructokinase in the proximal jejunum of the streptozotocin-diabetic rat was found to be diminished compared with normal from 13.4 to 10.4 units $/ g$ wet weight mucosa and the activity ratio of the enzyme at $\mathrm{pH} 7$ was diminished from 0.40 to 0.23 , indicating that the enzyme is more susceptible to inhibition by ATP. The combination of these changes is, in principle, more than sufficient to account for the $29 \%$ decrease in glucose utilisation observed in the jejunum of diabetic rats. Insulin, when injected
\end{abstract}

in vivo, has the ability to restore both the total activity and the regulatory properties of phosphofructokinase to normal in streptozotocin-diabetic rats. The action of insulin is blocked by the protein synthesis inhibitor cycloheximide, and is not mediated by changes in blood glucose levels.

Key words: Intestine, glucose utilisation, phosphofructokinase, diabetes, insulin.
It is well-established that glucose absorption by the epithelial cells of the small intestine is increased in rats with experimental diabetes compared with normal rats $[1,2]$. Two factors that contribute to the enhancement of glucose transport are an increased mucosal to serosal flux resulting from the induction by hyperglycaemia of the synthesis of new carrier sites in the basolateral membrane [3], and a decreased rate of glucose utilization by the intestine [4]. The mechanism responsible for the latter is considered here.

In studies with a vascularly-perfused preparation of jejunum, Hanson and Parsons [4] found that the rate of glucose utilization in streptozotocin-diabetic rats was decreased by about $29 \%$ compared with normal rats. The rate of glucose utilization in the muscularis is relatively small compared with that of the epithelial cells [5]; hence the decrease in glucose utilization primarily reflects an inhibition of the glucose metabolism of the epithelial cells in streptozotocin-diabetic rats. The decrease in utilisation cannot be explained by changes in the levels of glycolytic enzymes, such as hexokinase [6] for the latter are increased in diabetic rats [7]; nor can it be explained by the large intramucosal accumulation of glucose that occurs in diabetic rats $[3,8]$ since the rates of utilisation by jejunum from normal and diabetic rats were determined in vitro at the same glucose concentration [4]. Some other factor is therefore implicated in the control of intestinal glucose metabolism in experimental diabetes.
We have suggested recently that the mechanism whereby glucose utilization is decreased in another condition in which the circulating levels of insulin are also depressed, that of starvation, is through the control of phosphofructokinase activity [9]. Thus, when rats are starved for $48 \mathrm{~h}$, the activity of mucosal phosphofructokinase is reduced in two ways. First, the regulatory properties of the enzyme are altered in that it is much more susceptible to inhibition by ATP and second, the total activity (units/g wet weight) is reduced by some $20 \%$. The combination of these two changes is sufficient to account, in principle, for the $64 \%$ reduction in glucose utilization rate observed by Hanson and Parsons for a vascularly-perfused preparation of jejunum from rats starved for $48 \mathrm{~h}$ compared with fed rats [4].

We report here that changes in the activity of mucosal phosphofructokinase, similar to those seen on starvation, also occur in the rat small intestine during the onset of experimental diabetes induced by streptozotocin.

\section{Materials and Methods}

Female CFHB Wistar or Leeds Wistar rats weighing between 225 and $250 \mathrm{~g}$ were fed standard laboratory diet ad libitum (Oxoid, Basingstoke, U.K., modifired 41 B) with free access to water. Diabetes was induced by a single IV injection of streptozotocin $(65 \mathrm{mg} / \mathrm{kg}$ body weight). The streptozotocin $(50 \mathrm{~g} / \mathrm{l})$ was dissolved in sodium citrate buffer $(50 \mathrm{mmol} / 1, \mathrm{pH} 4.5)$, immediately before use. Rats showing 


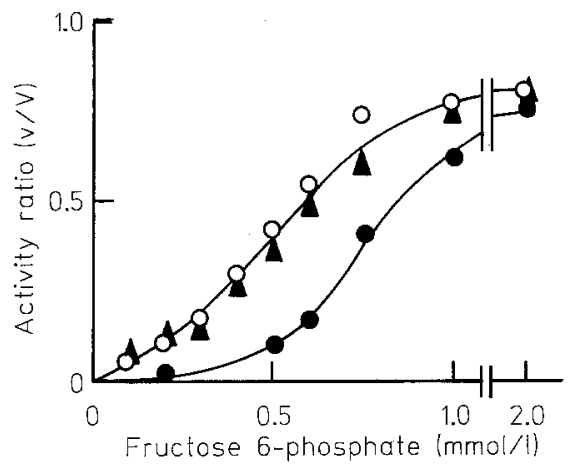

Fig. 1. The effect of streptozotocin diabetes on the regulatory properties of phosphofructokinase in crude extracts of rat jejunal mucosa from normal rats $\mathrm{O}-\mathrm{O}$ ), streptozotocin-diabetic rats $(-\mathbf{O})$ and streptozotocin-diabetic rats maintained on insulin for $25 \mathrm{~h}(-\mathbf{\Delta})$. The dependence of activity ratio on fructose 6-phosphate concentration was measured in the presence of $2.5 \mathrm{mmol} / 1$ ATP

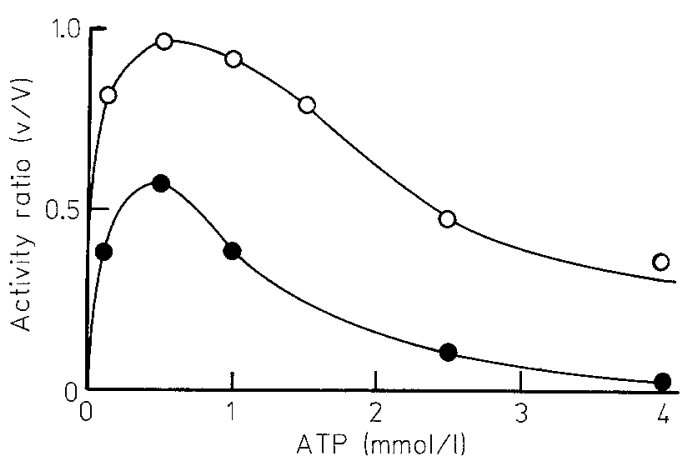

Fig.2. The effect of streptozotocin-diabetes on the regulatory properties of phosphofructokinase. The dependence of activity ratio on ATP concentration was measured in the presence of $0.5 \mathrm{mmol} / 1$ fructose 6 phosphate. Other details and symbols as for Figure 1

Table 1. The total activity of mucosal phosphofructokinase and its susceptibility to inhibition by ATP in the proximal jejunum and distal ileum of normal and streptozotocin-diabetic CHFB Wistar rats

\begin{tabular}{|c|c|c|c|c|}
\hline \multirow{3}{*}{$\begin{array}{l}\text { Experi- } \\
\text { mental } \\
\text { group }\end{array}$} & \multirow{3}{*}{$\begin{array}{l}\text { Intestinal } \\
\text { segment }\end{array}$} & \multicolumn{3}{|c|}{ Phosphofructokinase activity } \\
\hline & & \multicolumn{3}{|l|}{ Total activity } \\
\hline & & $\begin{array}{l}\text { Units/g wet } \\
\text { weight }\end{array}$ & $\begin{array}{l}\text { Units/mg } \\
\text { protein }\end{array}$ & $\mathrm{v}_{0.5} / \mathrm{V}$ \\
\hline \multirow[t]{2}{*}{ Normal } & $\begin{array}{l}\text { Proximal } \\
\text { Jejunum }\end{array}$ & $13.4 \pm 1.4(10)$ & $179 \pm 16(4)$ & $0.40 \pm 0.5$ \\
\hline & $\begin{array}{l}\text { Distal } \\
\text { Ileum }\end{array}$ & $4.6 \pm 0.5(6)$ & $70 \pm 15(4)$ & $0.42 \pm 0.05(6)$ \\
\hline \multirow[t]{2}{*}{ Diabetic } & $\begin{array}{l}\text { Proximal } \\
\text { Jejunum }\end{array}$ & $10.4 \pm 1.6(10)^{\mathrm{a}}$ & $96 \pm 15(4)^{a}$ & $0.23 \pm 0.07(8)^{\mathrm{a}}$ \\
\hline & $\begin{array}{l}\text { Distal } \\
\text { Ileum }\end{array}$ & $5.9 \pm 0.8$ & $62 \pm 7(4)$ & $0.26 \pm 0.05(6)^{\mathrm{a}}$ \\
\hline
\end{tabular}

Values are given as mean $\pm \mathrm{SD}$ with numbers of rats in parentheses. The total activity of mucosal phosphofructokinase was measured under optimal conditions at pH 8 as described in Materials \& Methods; the susceptibility of phosphofructokinase to inhibition by ATP was measured by changes in the activity ratio $\left(\mathrm{v}_{0.5} / \mathrm{V}\right)$ of the activity determined at $\mathrm{pH} 7.0$ in the presence of $0.5 \mathrm{mmol} / 1$ fructose- 6 -phosphate and ATP $(2.5 \mathrm{mmol} / \mathrm{l})$ at $\mathrm{pH} 7.0$. Significant differences from normal rats: ${ }^{a} p<0.001$ positive glycosuria ( $>400 \mathrm{mg} / 100 \mathrm{ml}$; Boehringer, London, UK test strip) 4 and 5 days after injection were used. The results obtained showed no obvious relationship to the period of diabetes and have been pooled.

In order to reverse the effects of diabetes, normal and 4-day streptozotocin-diabetic rats received either three or four IP injections of insulin $(20 \mathrm{U} / \mathrm{kg}$ body weight in $50 \mathrm{mmol} / 1$ sodium phosphate buffer, $\mathrm{pH} 7.1$ ) at $8 \mathrm{~h}$ intervals, commencing $17 \mathrm{~h}$ or $25 \mathrm{~h}$, respectively before removal of tissue; thus rats were used in each case $1 \mathrm{~h}$ after the final injection of insulin.

The effect of cycloheximide was observed in streptozotocin-diabetic rats maintained on insulin for $25 \mathrm{~h}$ as described above. Cycloheximide solution $(1 \mathrm{~g} / 1$ in $0.9 \%$ saline) was injected IP ( $3 \mathrm{ml} / \mathrm{kg}$ body weight) at $13 \mathrm{~h}$ and $2.5 \mathrm{~h}$ before tissue removal as described by Crouzoulon and Dandrifosse [10].

Experimental hyperglycaemia was produced in normal rats under anaesthesia as follows. The femoral vein was cannulated and rats received a priming dose of $1.15 \mathrm{~g}$ of glucose in heparinised KrebsHenseleit bicarbonate medium ( $0.31 \mathrm{~g}$ heparin $/ \mathrm{l})$, followed by an infusion of glucose $(30 \% \mathrm{w} / \mathrm{v})$ in saline $(0.9 \% \mathrm{NaCl})$ at a rate of $2 \mathrm{ml} / \mathrm{h}$ for $4 \mathrm{~h}$. The blood glucose level was thus maintained above $44 \mathrm{mmol} / 1$ for the whole of the infusion. Control rats received an infusion only of saline $(0.9 \% \mathrm{NaCl})$.

The daily food intakes of normal and streptozotocin-diabetic rats were measured at $10.00 \mathrm{~h}$ using female Leeds Wistar rats $(220-250 \mathrm{~g})$.

Extracts of intestinal mucosa were prepared and phosphofructokinase activity assayed as described previously [9].

Data on the regulatory properties of mucosal phosphofructokinase are presented as the activity ratio ( $\mathrm{V} / \mathrm{V}$ ) where $\mathrm{v}$ is the suboptimal activity at $\mathrm{pH} 7.0$ in the presence of ATP $(2.5 \mathrm{mmol} / 1)$ and a given concentration of fructose 6-phosphate under the conditions defined by Hussey et al. [11] and $\mathrm{V}$ is the maximal activity at $\mathrm{pH} 8.0$, where the enzyme is not subject to allosteric regulation, determined according to Ling et al. [12]. In this way, the effects of streptozotocin diabetes on the regulatory properties and on the total activity of mucosal phosphofructokinase could be distinguished. One unit of activity is defined as the formation of $1 \mu \mathrm{mol}$ of fructose 1,6-biphosphate per min at $27^{\circ} \mathrm{C}$.

Biochemicals were obtained from the Sigma, London or Boehringer and other reagents were of analytical grade.

\section{Statistical Analysis}

The data are expressed as mean $\pm \mathrm{SD}$, and Comparisons between sets of data were made using the Student's t-test.

\section{Results}

The regulatory properties of phosphofructokinase from rat intestinal mucosa are altered during the onset of streptozotocin diabetes. Figure 1 shows that in 4- and 5day streptozotocin-diabetic rats, the fructose 6-phosphate saturation curve of jejunal phosphofructokinase, measured under suboptimal conditions in the presence of ATP $(2.5 \mathrm{mmol} / \mathrm{l})$ at $\mathrm{pH} 7.0$, is displaced to higher fructose 6-phosphate concentrations. The apparent $\mathrm{K}_{\mathrm{M}}$ of the enzyme for fructose 6-phosphate in normal rats was $0.47 \mathrm{mmol} / 1 \mathrm{compared}$ with $0.75 \mathrm{mmol} / 1$ in streptozotocin-diabetic rats. The increase in $\mathrm{K}_{\mathrm{M}}$ is a reflection of an increased susceptibility to inhibition by ATP (Fig. 2). Figure 1 shows that the difference in the phosphofructokinase activity ratio at $0.5 \mathrm{mmol} / 1$ fructose 6 phosphate $\left(\mathrm{v}_{0.5} / \mathrm{V}\right)$ between normal and streptozotocindiabetic rats was about maximal. In further investiga- 
Table 2. Daily food intake of normal and streptozotocin-diabetic rats

\begin{tabular}{llllll}
\hline $\begin{array}{l}\text { Experi- } \\
\text { mental } \\
\text { group }\end{array}$ & \multicolumn{4}{l}{ Food intake $(\mathrm{g})$} & \\
\cline { 2 - 6 } & Day 1 & Day 2 & Day 3 & Day 4 & Day 5 \\
\hline $\begin{array}{l}\text { Normal } \\
(6)\end{array}$ & $40,1 \pm 0.4$ & $34.7 \pm 5.0$ & $36.7 \pm 5.0$ & $39.6 \pm 3.9$ & $35.9 \pm 4.5$ \\
$\begin{array}{l}\text { Diabetic } \\
(6)\end{array}$ & $19.7 \pm 1.7^{\mathrm{a}}$ & $18.4 \pm 4.2^{\mathrm{b}}$ & $31.4 \pm 3.2$ & $34.5 \pm 4.8$ & $41.4 \pm 5.7$ \\
& & & & & \\
\end{tabular}

Values are given as mean $\pm S D$ with numbers of rats in parentheses. Female Leeds Wistar rats $(220-250 \mathrm{~g})$ were made diabetic by the injection of streptozotocin and their daily food intake monitored against that of normal rats. Significant differences from normal rats are denoted: ${ }^{a} p<0.005 ;{ }^{b} p<0.01$

Table 3. The effect of insulin in vivo on mucosal phosphofructokinase activity in the proximal jejunum after intraperitoneal injection into normal and streptozotocin-diabetic Leeds Wistar rats

\begin{tabular}{lcc}
\hline Experimental group & \multicolumn{2}{c}{ Phosphofructokinase activity } \\
\cline { 2 - 3 } & $\begin{array}{l}\text { Total activity } \\
\text { (units/g wet weight) }\end{array}$ & $\mathrm{v}_{0.5} / \mathrm{V}$ \\
\hline Normal & $14.4 \pm 2.2(6)$ & $0.39 \pm 0.04(9)$ \\
Normal + insulin $(25 \mathrm{~h})$ & $14.7 \pm 0.5(3)$ & $0.36 \pm 0.01(3)$ \\
Diabetic & $10.5 \pm 0.9(5)^{\mathrm{c}}$ & $0.12 \pm 0.03(5)^{\mathrm{a}}$ \\
Diabetic + insulin $(17 \mathrm{~h})$ & $11.1 \pm 1.7(3)^{\mathrm{d}}$ & $0.21 \pm 0.02(3)^{\mathrm{b}}$ \\
Diabetic+insulin $(25 \mathrm{~h})$ & $14.0 \pm 1.4(3)$ & $0.39 \pm 0.07(3)$ \\
Diabetic + cycloheximide & $9.2 \pm 1.3(4)^{\mathrm{a}}$ & $0.13 \pm 0.02(6)^{\mathrm{a}}$ \\
$\quad$ +insulin (25 h) & & \\
Diabetic + cycloheximide (25 h) & $9.0 \pm 0.8(3)^{\mathrm{a}}$ & $0.13 \pm 0.03(3)^{\mathrm{a}}$ \\
\hline
\end{tabular}

Values are given as mean \pm SD with numbers of rats in parentheses. Significant differences from normal rats are denoted: ${ }^{\mathrm{a}} p<0.001,{ }^{\mathrm{b}} p<$ $0.005,{ }^{\mathrm{c}} p<0.01,{ }^{\mathrm{d}} p<0.05$

tions of the regulatory properties of phosphofructokinase using multiple samples of the proximal jejunal and distal ileal segments of intestine, $\mathrm{v}_{0.5} / \mathrm{V}$ was therefore determined.

Normal rats displayed a negative aboral gradient of total phosphofructokinase activity, falling from $13.4 \pm$ 1.4 units/g wet weight mucosa, in the proximal jejunum to about $34 \%$ of that value in the distal ileum (Table 1 ). In streptozotocin-diabetic rats, the total activity in the proximal jejunum was diminished by about $23 \%$ ( $p<$ 0.001 ) in comparison with normal rats, whereas no significant change was observed in the distal ileum. In contrast to the changes in total activity, the activity ratio $\mathrm{v}_{0.5} / \mathrm{V}$ in normal rats was the same in the distal ileum as in the proximal jejunum and both were almost halved, from about 0.41 to about $0.23(\mathrm{p}<0.001)$ in streptozotocin-diabetic rats.

Although the increased susceptibility of mucosal phosphofructokinase to inhibition by ATP in streptozotocin-diabetic rats was similar to that seen in starved rats, it was not the consequence of semi-starvation during the induction of diabetes by streptozotocin. Thus, whereas food intake was significantly reduced on days 1 and 2 after injection of rats with streptozotocin compared with normal rats, as was the case with mice [13], the intake had returned to normal by day 3 (Table 2 ). Moreover, as refeeding of starved rats for only $16 \mathrm{~h}$ was sufficient to restore both the total activity and the activity ratio of mucosal phosphofructokinase to those characteristic of normal, fed rats [9], the diminished values observed in 4- and 5-day streptozotocin-diabetic rats could not have been caused by the initial reduction in food intake on days 1 and 2 .

CHFB Wistar rats were used for the early experiments of this study (Table 1). In subsequent experiments a stress-resistant strain, Leeds Wistar rat, was used. When the latter rats were made diabetic, the susceptibility of mucosal phosphofructokinase from the proximal jejunum to inhibition by ATP was even greater than for CHFB Wistar rats, the activity ratio, $\mathrm{v}_{0.5} / \mathrm{V}$, being diminished from a normal value for Leeds Wistar rats of $0.39 \pm 0.04$ to as little as $0.12 \pm 0.03(p<0.001)$ rather than the value of 0.23 for CHFB Wistar rats (Table 3). As was the case for CHFB Wistar rats, the total activity of phosphofructokinase was significantly reduced in Leeds Wistar rats that were streptozotocin-diabetic.

The effects of streptozotocin-diabetes on the total activity and on the regulatory properties of mucosal phosphofructokinase from the jejunum could be completely reversed by the administration of insulin in vivo (Table 3). In particular, the IP injection of 4-day streptozotocin-diabetic rats with insulin ( $20 \mathrm{U} / \mathrm{kg}$ body weight) at $8 \mathrm{~h}$ intervals resulted in an increase in the value of $\mathrm{v}_{0.5} / \mathrm{V}$ from $0.12 \pm 0.03$ to $0.21 \pm 0.02$ after $17 \mathrm{~h}$ and then to $0.39 \pm 0.07$ after $25 \mathrm{~h}$ when the fructose 6 -phosphate saturation curve was indistinguishable from that for normal rats (Fig. 1). The ability of insulin to restore both the total activity of phosphofructokinase and its susceptibility to inhibition by ATP to normal in streptozotocin-diabetic rats was completely blocked by cycloheximide; no changes were seen in diabetic rats injected with insulin and cycloheximide compared with diabetic rats injected only with cycloheximide or untreated diabetic rats (Table 3 ). The treatment of normal rats with insulin for $25 \mathrm{~h}$ did not produce any chance in $\mathrm{v}_{0.5} / \mathrm{V}$ or in total activity (Table 3 ).

A $4 \mathrm{~h}$ period of experimental hyperglycaemia during which blood glucose was maintained above $44 \mathrm{mmol} / \mathrm{l}$ by IV glucose infusion into an anaesthetised, normal rat was without effect on either the total activity or the activity ratio of mucosal phosphofructokinase in the proximal jejunum and distal ileum (Table 4).

\section{Discussion}

Previous studies with starved rats led us to suggest that mucosal phosphofructokinase plays an important role in the regulation glucose utilization [9] and further support for this suggestion is provided in the present study. Thus, in streptozotocin-diabetic CHFB Wistar rats, the total activity of mucosal phosphofructokinase in the je- 
Table 4. The effect of hyperglycaemia on the total activity of mucosal phosphof ructokinase and its susceptibility to inhibition by ATP in the proximal jejunum and distal ileum in normal rats

\begin{tabular}{|c|c|c|c|}
\hline \multirow{2}{*}{$\begin{array}{l}\text { Experi- } \\
\text { mental } \\
\text { group }\end{array}$} & \multirow{2}{*}{$\begin{array}{l}\text { Intestinal } \\
\text { segment }\end{array}$} & \multicolumn{2}{|c|}{ Phosphofructokinase activity } \\
\hline & & $\begin{array}{l}\text { Total activity } \\
\text { (units/g wet weight) }\end{array}$ & $\mathrm{v}_{0.5} / \mathrm{V}$ \\
\hline $\begin{array}{l}\text { Normal } \\
\text { control }\end{array}$ & $\begin{array}{l}\text { Proximal } \\
\text { Jejunum } \\
\text { Distal } \\
\text { Ileum }\end{array}$ & $\begin{array}{r}14.9 \pm 1.1(4) \\
7.0 \pm 0.9(4)\end{array}$ & $\begin{array}{l}0.39 \pm 0.03(4) \\
0.45 \pm 0.05(4)\end{array}$ \\
\hline $\begin{array}{l}\text { Normal } \\
\text { hypergly- } \\
\text { caemic }\end{array}$ & $\begin{array}{l}\text { Proximal } \\
\text { Jejunum } \\
\text { Distal } \\
\text { Ileum }\end{array}$ & $\begin{array}{r}15.4 \pm 1.6(4) \\
6.7 \pm 0.8(4)\end{array}$ & $\begin{array}{l}0.45 \pm 0.08(4) \\
0.42 \pm 0.06(4)\end{array}$ \\
\hline
\end{tabular}

Values are given as mean \pm SD with numbers of rats in parentheses. Anaesthetised normal Leeds Wistar rats were maintained in a hyperglycaemic state for $4 \mathrm{~h}$ by glucose infusion; controls were infused with $0.9 \%$ saline

junum is diminished by about $23 \%$ and the susceptibility to inhibition by ATP is increased so that the activity ratio is diminished by about $43 \%$. Hence, when both changes are taken into account, the overall decrease in activity under the specified conditions of the assay is some $56 \%$ for CHFB Wistar rats (Table 1); in the case of Leeds Wistar rats, the overall decrease is as much as $78 \%$ (Table 3). Although it is not possible to choose assay conditions in vitro that reflect physiological conditions in precise detail, it is apparent that changes in phosphofructokinase activity can, in principle, more than account for the $29 \%$ reduction in intestinal glucose utilization in streptozotocin-diabetic rats [4].

Our results show that the total activity of mucosal phosphofructokinase decreases aborally from the proximal jejunum to the distal ileum in normal rats, whereas the susceptibility to inhibition by ATP is unaltered. The same is true for streptozotocin-diabetic rats, although the gradient of total activity is diminished, entirely as a result of a decrease in the proximal jejunum but not the distal ileum, and the susceptibility to inhibition by ATP is much greater in both jejunum and ileum. Exactly equivalent changes in total activity and susceptibility to inhibition by ATP were seen when rats starved for $48 \mathrm{~h}$ were compared with fed rats and imply that the mechanism that controls the total activity of mucosal phosphofructokinase is distinct from that controlling changes in regulatory properties, although both are mediated by humoral factors [9]. The changes in phosphofructokinase activity reported here for 4- and 5-day streptozotocin-diabetic rats were not caused by semistarvation of rats during the onset of streptozotocin-diabetes (Table 2).

The ability of insulin to reverse the effects of streptozotocin diabetes on the total activity and on the susceptibility of mucosal phosphofructokinase to inhibition by ATP (Table 3) implicates insulin as one humoral factor, whether directly or indirectly. An obvious mechanism for the indirect control of phosphofructokinase activity by insulin is through changes in blood glucose levels. Thus, the inhibition of mucosal phosphofructokinase in streptozotocin-diabetic rats could be caused by hyperglycaemia, particularly in view of the fact that the intracellular concentration of glucose in epithelial cells is determined by and is similar to that of blood glucose [8] and the report by Porteous [14] that glucose utilization by chick enterocytes is diminished by about $21 \%$ when the concentration of glucose in the incubation medium is doubled to $10 \mathrm{mmol} / \mathrm{l}$.

However, no change was observed in either total mucosal phosphofructokinase activity or in the activity ratio when hyperglycaemia was produced in normal rats by glucose infusion for $4 \mathrm{~h}$ (Table 4 ). In such a situation, hyperglycaemia markedly stimulates insulin secretion and it is possible that an increase in total activity or activity ratio caused by insulin directly might have masked a corresponding decrease caused by hyperglycaemia. However, insulin injected into normal rats in the absence of hyperglycaemia did not affect either the total activity or the activity ratio (Table 3 ). In starved rats, which show a similar depression in the total activity and activity ratio of phosphofructokinase to that reported here for streptozotocin-diabetic rats, the blood glucose is depressed compared with normal [9].

The fact that cycloheximide completely blocks the ability of insulin to restore the total activity and activity ratio of mucosal phosphofructokinase to normal values in streptozotocin-diabetic rats indicates that protein synthesis is involved in the control of activity. In the case of changes in total phosphofructokinase activity, synthesis of new enzyme is most probably involved. Bazaes et al. [15] have reported recently that phosphofructokinase from the muscle of genetically diabetic mice (strain C57BL/KsJ) is more phosphorylated and slightly more susceptible to inhibition by ATP than from normal mice. It is possible that a similar explanation is involved in the changes in activity ratio of mucosal phosphofructokinase reported here. Equally, it is possible that the changes stem from alterations in the synthesis or activity of a different enzyme responsible for the production of an effector of phosphofructokinase; such a situation occurs in the regulation of phosphofructokinase in liver [16-20]. Hyperglycaemia is unlikely to be a factor in protein synthesis since the $4 \mathrm{~h}$ infusion, which results in a large increase in glucose carrier synthesis [3], was without effect on phosphofructokinase and diabetes results in a reduction in synthesis.

The intestine has traditionally been regarded as an insulin-insensitive tissue when studied in vitro while studies on the effect of insulin in vivo have been conflicting [1, 2]. Recently, however, evidence has been presented that enterocytes possess insulin-binding sites [21]. The present study clearly demonstrates that the injection of insulin into streptozotocin-diabetic rats restores the depressed activity of mucosal phosphofructokinase to normal. Although an indirect effect cannot be 
excluded, the balance of the present evidence inclines towards a direct effect of insulin on the epithelial cells of the intestine.

Acknowledgement. This work was supported in part by the British Diabetic Association. A.J. is the recipient of a Science and Engineering Research Council studentship.

\section{References}

1. Caspary WF (1973) The effect of insulin and diabetes mellitus on the digestive-absorptive function of the small intestine. Digestion 9: $248-263$

2. Levin RJ (1969) The effects of hormones on the absorptive, metabolic and digestive function of the small intestine. $J$ Endocrinol 45: $315-348$

3. Csaky TZ, Fischer E (1981) Intestinal transport in experimental diabetes. Diabetes 30:568-574

4. Hanson PJ, Parsons DS (1978) Factors affecting the utilisation of ketone bodies and other substrates by rat jejunum: effects of fasting and diabetes. J Physiol 278: 55-67

5. Leese HJ, Bronk JR (1975) Lactate formation by rat small intestine in vitro. Biochem Biophys Acta 404: 40-48

6. Srivastava LM, Hubscher G (1966) Glucose metabolism in the mucosa of the small intestine; glycolysis in subcellular preparations from the cat and rat. Biochem J 100: 458-466

7. Anderson JW (1974) Glucose metabolism in jejunal mucosa of fed, fasted and streptozotocin-diabetic rats. Amer. J. Physiol. 226: 226-229

8. Leese $\mathrm{HJ}$ (1974) Glucose accumulation by rat small intestine during absorption in vivo. Nature 251: 512-513

9. Jamal A, Kellett GL (1983) The effect of starvation on the control of phosphofructokinase activity in the epithelial cells of the rat small intestine. Biochem J 210: 129-135

10. Crouzoulon G, Dandrifosse G (1979) Dietary regulation of fructose metabolism in the intestine and in the liver of the rat: time response and effect of cycloheximide. Int J Biochem 10: 439-447

11. Hussey CR, Liddle PF, Ardron D, Kellett GL (1977) The isolation and characterisation of differentially phosphorylated fractions of phosphofructokinase from rabbit skeletal muscle. Eur J Biochem 80: 497-506
12. Ling K-H, Marcus F, Lardy HA (1965) Purification and some properties of rabbit skeletal muscle phosphofructokinase. J Biol Chem 240: 1893-1899

13. Pothier D, Hugon TS (1982) Immediate and localised response of intestinal mucosal enzyme activities in streptozotocin-diabetic mice. Comp Biochem Physiol 72A: 505-513

14. Porteous JW (1980) Glutamate, glutamine, aspartate, asparagine and ketone-body metabolism in chick intestinal bush-border cells. Biochem J 188: 619-632

15. Bazaes SE, Foe LG, Kemp RG (1982) Phosphate content of muscle phosphofructokinase in the genetically diabetic mouse (C57BL/KsJ) Arch Biochem Biophys 218: 483-487

16. Nieto A, Castano JG (1980) Control in vivo of rat liver phosphofructokinase by glucagon and nutritional changes. Biochem J 186: 953-957

17. van Schaftingen E, Hue L, Hers H-G (1980a) Control of the fructose 6-phosphate/fructose 1,6-bisphosphate cycle in isolated hepatocytes by glucose and glucagon. Biochem J 192: 887-895

18. van Schaftingen E, Hue L, Hers H-G (1980b) Fructose 2 6-bisphosphate, the probable structure of the glucose- and glucagonsensitive stimulator of phosphofructokinase. Biochem J 192: 897-901

19. Neely P, El-Maghrabi MR, Pilkis SJ, Claus TH (1981) Effect of diabetes, insulin, starvation and refeeding on the level of rat hepatic fructose 2,6-bisphosphate. Diabetes 30: 1062-1064

20. Kuwajima M, Uyeda K (1982) The tissue distribution of fructose 2,6-bisphosphate and fructose 6-phosphate, 2-kinase in rats and the effect of starvation, diabetes and hypoglycaemia on hepatic fructose 2,6-bisphosphate and fructose 6-phosphate, 2-kinase. Biochem Biophys Res Commn 104: 84-88

21. Forgue-Lafitte ME, Marescot MR, Chamberlin MC, Rosselin G (1980) Evidence for the presence of insulin binding sites in isolated rat intestinal cells. Diabetologia 19:373-378

Received: 25 February 1983

and in final form: 15 July 1983

Dr. G. L. Kellett

Department of Biology

University of York

Heslington

York Y01 5DD

UK 